\title{
Prevalence and factors associated with chronic neuropathic pain in workers of a Brazilian public university
}

\author{
Prevalência e fatores associados à dor neuropática crônica em trabalhadores de uma \\ universidade pública brasileira
}

Igor Garcia Barreto', Katia Nunes Sá2

DOI 10.5935/2595-0118.20190020

\section{ABSTRACT}

BACKGROUND AND OBJECTIVES: Although it is a public health problem, the prevalence of chronic pain, especially in workers, is underestimated. The present study aims to estimate the prevalence of chronic pain and chronic neuropathic pain in workers of a federal public institution and to identify the associated factors.

METHODS: A cross-sectional study conducted in a stratified random sample of civil servants of a federal higher education institution, between October 2017 and March 2018. Standardized questionnaires involving sociodemographic characteristics and life habits were applied. For those with chronic pain (duration equal to or greater than three months), a questionnaire with pain characteristics was also applied, including a body map, the visual analog scale, and the neuropathic pain questionnaire Doleur Neuropathic 4. The prevalence of chronic pain was estimated, and the Poisson model was used to test the associations between variables ( $5 \%$ of alpha).

RESULTS: In a sample of 108 active civil servants, chronic pain was found in $50 \%$ of the sample $(95 \% \mathrm{CI}=40.6-59.4)$ and chronic neuropathic pain in 12\% (CI 95\%=6.9-19.2). No associations were found between chronic pain and sociodemographic characteristics or life habits. An independent association was confirmed between the frequency of pain and neuropathic pain, where continuous pain in relation to the occasional pain showed a prevalence ratio of $5.17(\mathrm{CI} 95 \% \mathrm{CI}=1.69-15.79$, $\mathrm{p}=0.004)$.

CONCLUSION: Chronic pain had a high prevalence in the institution, being continuous in workers with neuropathic pain. The severity of this type of pain requires urgent actions for its control. Keywords: Chronic pain, Pain measurement, Risk factors.

\footnotetext{
Igor Garcia Barreto - Dhttps://orcid.org/0000-0003-3674-2826;

Katia Nunes Sá - (Ohttps://orcid.org/0000-0002-0255-4379.

1. Universidade Federal do Recôncavo da Bahia, Cruz das Almas, BA, Brasil.

2. Escola Bahiana de Medicina e Saúde Pública, Salvador, BA, Brasil.

Submitted on December 11, 2018

Accepted for publication on March 20, 2019.

Conflict of interests: none - Sponsoring sources: none.

Correspondence to:

Pró-Reitoria de Gestẫo de Pessoas

Rua Rui Barbosa, 710

44380-000 Cruz das Almas, BA, Brasil.

E-mail: igbarreto2@gmail.com

(C) Sociedade Brasileira para o Estudo da Dor
}

\section{RESUMO}

JUSTIFICATIVA E OBJETIVOS: Embora seja um problema de saúde pública, a prevalência de dor crônica, especialmente em trabalhadores, é subestimada. O presente estudo teve o objetivo de estimar a prevalência de dor crônica e de dor neuropática crônica em trabalhadores de uma instituição pública federal e identificar os fatores associados.

MÉTODOS: Estudo de corte transversal conduzido em amostra aleatória estratificada de servidores de uma instituição de ensino superior federal, entre outubro de 2017 e março de 2018. Foram aplicados questionários padronizados envolvendo características sociodemográficas e hábitos de vida. Para os que tinham dor crônica (duração igual ou maior que três meses), foram também aplicados um questionário de características dolorosas, envolvendo um mapa corporal, a escala visual analógica e o questionário de dor neuropática Doleur Neuropathic 4. A prevalência de dor crônica foi estimada e o modelo de Poisson utilizado para testar as associaçōes entre as variáveis (alfa de 5\%).

RESULTADOS: Em uma amostra de 108 servidores ativos, a dor crônica foi encontrada em 50\% da amostra (IC95\%=40,659,4), sendo $12 \%$ (IC95\%=6,9-19,2) com características neuropáticas. Não foram encontradas associaçôes entre dor crônica e características sociodemográficas ou hábitos de vida. Foi confirmada a associação independente entre a frequência de dor e dor neuropática, onde a dor contínua em relaçáo à ocasional apresentou razáo de prevalência de 5,17 (IC95\%=1,69-15,79; p=0,004). CONCLUSÃO: A dor crônica apresentou elevada prevalência na instituição, sendo contínua em trabalhadores com dor neuropática. A gravidade desse tipo de dor exige açôes urgentes para seu controle. Descritores: Dor crônica, Fatores de risco, Mensuraçâo da dor.

\section{INTRODUCTION}

According to the International Association for the Study of Pain (IASP), chronic pain (CP) is the one that lasts longer than the expected period for tissue healing. The threshold of three months has been recognized as the most convenient for non-malignant pain ${ }^{1}$. $\mathrm{CP}$ causes great damage for the individual, such as reduction of quality of life (QoL) and psychiatric disorders, including anxiety ${ }^{2}$, insomnia ${ }^{3}$, and depression ${ }^{4}$. It also creates an enormous burden on society, since it causes considerable damage to the health care systems and is associated with significant losses of productivity ${ }^{5,6}$. In the United States alone, CP affects around 100 million adults, which is higher than the total of heart disease, cancer, and diabe- 
tes combined ${ }^{5}$. In addition to its high frequency, it also presents a low annual recovery rate, since $79 \%$ of the affected individuals still have the symptoms even after four years ${ }^{7}$. On a global scale, $\mathrm{CP}$ has reached epidemic proportions due to the increasing prevalence over the years ${ }^{8}$. In developed countries, its prevalence is estimated between 26.4 and $51.3 \%{ }^{7-10}$, while in Brazil, between 28.1 and $42 \%^{11-13}$. Due to its subjective nature, CP varies according to psychosocial, cultural and sociodemographic factors, which is why tracking and identification of associated factors become relevant.

$\mathrm{CP}$ can be classified as nociceptive or neuropathic. Neuropathic pain arises from injury or nervous system dysfunction ${ }^{14}$, and it is associated with more intense pain, in addition to being more difficult to treat ${ }^{15,16}$. Chronic neuropathic pain (CNP) causes more significant QoL impairment, mood disorders and difficulties in daily life activities ${ }^{17}$. Its treatment is very different from the effective treatment for nociceptive pain, being of utmost importance its differentiation. The careful evaluation of $\mathrm{CP}$, especially the CNP, is vital to address more effective measures for its control.

Despite the high social cost and magnitude of the problem, with the involvement of a significant portion of the population on productive age, few studies have been conducted in Brazil to check the prevalence of $\mathrm{CP}$ in work environments. In this context, back pain is a recurrent complaint ${ }^{18,19}$. When it comes to workers of the public sector, the damage caused by $\mathrm{CP}$ affects the whole society directly, since they pay the costs.

The present study aimed to estimate the prevalence of $\mathrm{CP}$ and $\mathrm{CNP}$, as well as to check the factors associated with this disease in a population of workers of a higher education federal institution.

\section{METHODS}

A cross-sectional study conducted at the Federal University of Recôncavo da Bahia (UFRB), at its campuses located in the cities of Cruz das Almas, Santo Antônio de Jesus, Amargosa, Cachoeira, Santo Amaro and Feira de Santana (Bahia-Brazil) between October 2017 and March 2018.

The active workers of UFRB were eligible for the study. According to data from March 2017, there were 1,496 active workers, of these 781 teachers and 715 administrative technicians. The exclusion criteria were pregnancy, workers at gestation leave, workers away for personal reasons, for health reasons, provided that the cause was not the $\mathrm{CP}$ and training, with a scheduled date for the end of the respective leaves after 30 days after the expected date to conclude the data collection. Employees working out of their main workplace and with difficulties to answer the questionnaires were also excluded. Workers who were away from their activities for less than the study period, such as in the case of leave, short leave or holidays, were interviewed after 30 days of returning to work.

The stratified random sample was performed with the Microsoft Excel' software using the following procedure: a) the list of all workers was divided by position (teachers or administrative technicians), b) the command "= random ( ) "was used to generate a random number assigned to each worker, c) the lists were sorted in ascending order based on the random number, d) the list was then followed strictly until the sample calculation was reached within each category. The stratification was performed due to significant wage and socio-cultural differences between these categories. With an estimated prevalence of CP of 41.4\%, as found in a study conducted in Salvador ${ }^{12}$, a sample was calculated by WinPepi, version 11.65, with a $95 \%$ confidence interval (CI) and an acceptable difference of $9 \%$, of 56 teachers and 52 administrative technicians.

The participants selected were invited to the study via institutional email or telephone contact. For those who indicated an intention to participate, individual face-to-face interviews were scheduled with a single investigator, a labor physician who performed the collection in a standardized manner.

First, a questionnaire was applied involving sociodemographic information and lifestyle. In the end, individuals were asked about the presence of pain and, if so, how long they have had the problem. The minimum duration of three months was used as the classification criteria for CP. Participants with CP then answered a questionnaire about pain characteristics, with a body map to identify the sites with the worst pain, a visual analog scale, ranging from "zero", without pain, to " 10 ", the worst pain possible, in addition to questions about the frequency of pain and if they have had any treatment for it.

The Doleur Neuropathic 4 (DN-4) questionnaire was used to differentiate the type of pain between neuropathic or nociceptive, which was validated for Brazilian Portuguese, showing good validity and reliability ${ }^{21}$. The participants answered two questions, involving seven pain symptoms. Each item had "yes" or "no" answers. Each "no" answer received a "zero" score, and each "yes" received a "1". Participants with a score greater than or equal to 3 were classified as neuropathic pain. When using this strategy, the instrument has a sensitivity of $81.6 \%$ and specificity of $85.7 \%$ in the detection of neuropathic pain ${ }^{20}$.

The Human Research Ethics Committees of the Escola Baiana de Medicina e Saúde Pública (Medicine and Public Health Care School of Bahia), and Universidade Federal do Recôncavo da Bahia (Federal University of the Recôncavo of Bahia), approved the present study under numbers 69348117.8.0000.5544 and 69348117.8.3001.0056, respectively. All the workers had the signatures collected in the Free and Informed Consent Form (FICT).

\section{Statistical analysis}

All data were tabulated and analyzed by Stata for Windows version 13.0 (StataCorp LP, College Station, TX, USA). The variables were presented descriptively in absolute numbers and proportions, and their prevalence were estimated by the number of affected individuals divided by the number of individuals exposed. Two analyses were performed after the descriptive statistic. The first one had as independent variables: age, gender, marital status, skin color, position, physical activities, smoking, alcoholism, education level and distance between the cities of residence and work, being the dependent variable the presence or not of CP. The second analysis used as independent variables, the time since the beginning of the pain symptoms, their intensity, 
location, frequency and if the patient was receiving any treatment for control. The type of pain (nociceptive or neuropathic) was the dependent variable.

The variable marital status was categorized as single, married, domestic partnership, divorced or widowed. The color of the skin was classified according to the criteria of the Brazilian Institute of Geography and Statistics (IBGE) as white, black, brown, yellow and indigenous, the latter category being excluded due to lack of representatives. For physical activity, the guidelines of the American College of Sports Medicine (ACSM) were used, defining as active individuals those who performed 30 minutes or more of physical activity (PA) with moderate intensity at least 5 days per week or 20 minutes of vigorous PA at least 3 days per week. The others were classified as sedentary ${ }^{21}$.

The educational level was categorized into 5 levels (high school or below, higher education, postgraduate, masters, doctorate or higher). The alcohol consumption was determined as moderate or excessive if the consumption was higher than weekly or in the presence of drunkenness. Less frequent use classified respondents as non-consumers. For smoking, the workers were divided into nonsmokers, former smokers, and current smokers. The location of the pain was categorized according to the segments of the body in the head and neck, lumbar spine, lower limbs, and upper limbs. The numerical variables were analyzed in their original form.

A high prevalence of the study outcome was expected due to previous population-based studies of CP. For this reason, the estimate of the prevalence ratio (PR) obtained by the Odds Ratio (OR) in logistic regression models became inadequate. Due to this problem, the Poisson regression with the sandwich estimator of the variance $^{22}$ was used in the present study, since this model presents estimates of the PR and its CI95\% similar to those obtained by the Mantel-Haenszel procedure, even with the use of more than one confounding variable and continuous covariates ${ }^{23}$.
An initial univariate analysis was performed in the two statistical analyzes cited. The variables that had a $\mathrm{p}<0.2$ were selected to enter the multivariate model. Through the "Backward" elimination process, the least significant variables were successively excluded until a $\mathrm{p}<0.1$ in the remnants was reached, which was used as the threshold for inclusion of the variables in the final multivariate model. Analysis with $\mathrm{p}<0.05$ was considered statistically significant.

\section{RESULTS}

Figure 1 shows the flowchart of the data collection.

As noted, 108 participants completed the questionnaires and were included in the study. The sociodemographic characteristics and lifestyle of the interviewed workers are shown in table 1. The workers in the sample had a mean age of $42.4 \pm 10.7$ years. The majority of them were male $(62 \%)$, married or in a domestic relationship $(60.2 \%)$. Regarding skin color, brown was the predominant $(48.6 \%)$, while white was $31.4 \%$, black $17.1 \%$ and yellow $2.9 \%$ of the sample. Teachers accounted for $51.9 \%$ of the participants, followed by lower level technicians, $32.4 \%$ and higher level, $15.7 \%$. In terms of educational level, the majority of the workers had a Ph.D. (39.8\%), followed by postgraduate or specialization (20.4\%), master's degree (18.5\%), higher education (13.9\%) and high school or lower $(7.4 \%)$.

Regarding life habits, the sample was predominantly composed of sedentary individuals (52.3\%), non-smokers (81.6\%) and non-consumers of alcoholic beverage $(75.5 \%)$. The distance between the city of residence and work had a median of zero and an interquartile range (IQR) of zero in the quartile of $25 \%$ and of 117.5 in the quartile of $75 \%$, indicating that most people live in the same city where they work.

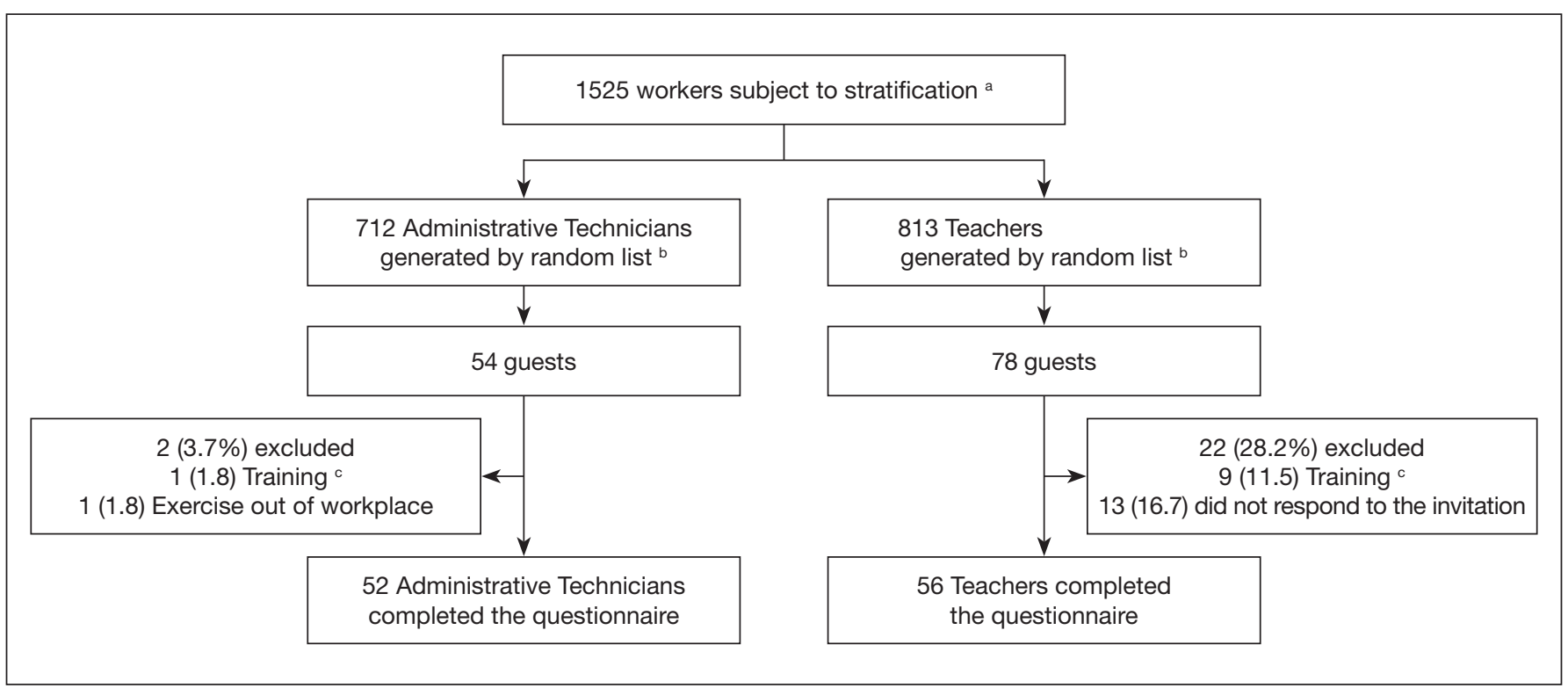

Figure 1. Data collection flowchart

a list generated with data from October/2017; b the command "= random 0" from the software Microsoft Excel was used to generate a random number associated with each worker. The lists of workers were then sorted in ascending order to obtain a random sequence; ${ }^{c}$ Training refers to the long-term absence of service for a master's, doctorate or postdoctoral degree. 
Table 1. Sociodemographic profile and lifestyle of the UFRB workers sample

\begin{tabular}{|c|c|}
\hline Variables & Total $(n=108)$ \\
\hline \multicolumn{2}{|l|}{ Age (years) } \\
\hline Mean \pm SD & $42.4 \pm 10.7$ \\
\hline \multicolumn{2}{|l|}{ Gender } \\
\hline Male ( $\mathrm{n}$ and \%) & $67(62)$ \\
\hline Female ( $\mathrm{n}$ and \%) & $41(38)$ \\
\hline \multicolumn{2}{|l|}{ Marital status } \\
\hline Single ( $\mathrm{n}$ and \%) & $36(33.3)$ \\
\hline Married or domestic part ( $\mathrm{n}$ and \%) & $65(60.2)$ \\
\hline Divorced or widowed ( $\mathrm{n}$ and \%) & $7(6.5)$ \\
\hline \multicolumn{2}{|l|}{ Skin color ${ }^{a}$} \\
\hline White ( $\mathrm{n}$ and \%) & $33(31.4)$ \\
\hline Black ( $\mathrm{n}$ and \%) & $18(17.1)$ \\
\hline Brown (n and \%) & $51(48.6)$ \\
\hline Yellow (n and \%) & $3(2.9)$ \\
\hline \multicolumn{2}{|l|}{ Position } \\
\hline Teacher ( $\mathrm{n}$ and \%) & $56(51.9)$ \\
\hline Higher education technician ( $\mathrm{n}$ and \%) & $17(15.7)$ \\
\hline $\begin{array}{l}\text { high school or less educational technician } \\
\text { ( } \mathrm{n} \text { and \%) }\end{array}$ & $35(32.4)$ \\
\hline \multicolumn{2}{|l|}{ Physical activity } \\
\hline Active (n and \%) & $51(47.7)$ \\
\hline Sedentary ( $\mathrm{n}$ and \%) & $56(52.3)$ \\
\hline \multicolumn{2}{|l|}{ Smoking } \\
\hline Yes (n and \%) & $6(5.8)$ \\
\hline No (n and \%) & $84(81.6)$ \\
\hline Ex-smoker ( $\mathrm{n}$ and \%) & $13(12.6)$ \\
\hline \multicolumn{2}{|l|}{ Alcohol consumption } \\
\hline No (n and \%) & $80(75.5)$ \\
\hline Moderate or excessive ( $\mathrm{n}$ and \%) & $26(24.5)$ \\
\hline \multicolumn{2}{|l|}{ Education level } \\
\hline High school or lower (n and \%) & $8(7.4)$ \\
\hline Higher education ( $\mathrm{n}$ and \%) & $15(13.9)$ \\
\hline Postgraduate or specialization ( $\mathrm{n}$ and \%) & $22(20.4)$ \\
\hline Master's degree (n and \%) & $20(18.5)$ \\
\hline Ph.D. (n and \%) & $43(39.8)$ \\
\hline \multicolumn{2}{|l|}{$\begin{array}{l}\text { Distance between the city of residence and } \\
\text { work in } \mathrm{km}\end{array}$} \\
\hline Median (IQI) & $0(0-117.5)$ \\
\hline
\end{tabular}

Of the 108 participants, 54 were positively tracked for $\mathrm{CP}$, resulting in a prevalence of $50 \%(\mathrm{CI} 95 \%=40.6-59.4)$. The pain time had a median of 28.5 months (IQI: 16.5-61.0), and the pain intensity had a mean of $5.55 \pm 1.76$. Low back pain was the major cause of CP in the sample, affecting 22 individuals (41.5\%), followed by pain in the upper limbs present in 13 (24.5\%), lower limbs in $11(20.8 \%)$ and head and neck pain in $7(13.2 \%)$. The pain was occasional in 31 people $(57.4 \%)$, and the majority of the workers $(66.7 \%)$ were not receiving any treatment for it. Regarding the type of pain, 41 individuals $(75.9 \%)$ had nociceptive pain characteristics, while only 13 had neuropathic pain. This data allows the calculation of the prevalence of $\mathrm{CP}$ with neuropathic characteristics of $12 \%(95 \% \mathrm{CI}=6.9-19.2)$ (Table 2). An analysis was performed involving possible factors associated with the presence of $\mathrm{CP}$ in the worker's sample, using the Poisson model with a robust estimator of the variance. In the univariate analysis, no statistically significant associations were found among the variables. Of the possible factors associated with $\mathrm{CP}$ in the sample, only the gender reached the pre-specified threshold of $\mathrm{p}<0.2$ for multivariate analysis, justifying its non-performance (Table 3 ).

A second analysis was performed to test possible associations between the pain characteristics and the probability of having CP with neuropathic characteristics. In the univariate analysis, it was observed that the time, intensity and frequency of pain variables reached the thresholds of $\mathrm{p}<0.2$ and entered the initial multivariate model (Table 4).

After the Backward elimination procedure, only the variable pain frequency remained significant enough to enter the final model, where a $\mathrm{p}=0.004$ was observed. When analyzing the factors, it was noted that this association was due to a PR of $5.17(95 \%$ $\mathrm{CI}=1.69-15.79)$ for ongoing pain in relation to the occasional pain (Table 5).

Table 2. Characterization of pain among chronic pain patients in the UFRB workers sample

\begin{tabular}{lc}
\hline Variables & Total $(\mathrm{n}=54)$ \\
\hline Time of pain (in months) & $28.5(16.5-61.0)$ \\
Median (IQI) & \\
Pain intensity & $5.55 \pm 1.76$ \\
Mean \pm SD & \\
Location of pain ( $\mathrm{n}$ and \%) ä & $7(13.2)$ \\
Head and neck & $22(41.5)$ \\
Lumbar spine & $13(24.5)$ \\
Upper limbs & $11(20.8)$ \\
Lower limbs & \\
Pain frequency ( $\mathrm{n}$ and \%) & $31(57.4)$ \\
Occasional & $17(31.5)$ \\
Daily & $6(11.1)$ \\
Continuous & \\
Treatment for pain (n and \%) & $18(33.3)$ \\
Yes & $36(66.7)$ \\
No &
\end{tabular}

$\mathrm{SD}=$ standard deviation; $\mathrm{IQI}$ = interquartile interval; ${ }^{\text {a there }}$ were no participants with thoracic spine pain. 
Table 3. Univariate analysis of the factors associated with chronic pain among UFRB workers $(n=108)$

\begin{tabular}{|c|c|c|c|}
\hline Variables & Chronic pain & Gross PR (Cl95\%) ${ }^{b}$ & $p$-value \\
\hline Age & & & 0.74 \\
\hline Mean \pm SD & $42 \pm 11$ & $1(0,98-1,01)^{c}$ & \\
\hline Male (\%) & $30(27.8)$ & 1 & \\
\hline Female (\%) & $24(22.2)$ & $1.31(0.89-1.90)$ & \\
\hline Marital status & & & 0.87 \\
\hline Married or domestic part. (\%) & $35(32.4)$ & $1.88(0.52-6.81)$ & \\
\hline Divorced or widowed (\%) & $2(1.19)$ & 1 & \\
\hline Skin color ${ }^{a}$ & & & 0.39 \\
\hline White (\%) & $18(17.1)$ & $1.63(0.22-11.91)$ & \\
\hline Black (\%) & $10(9.5)$ & $1.67(0.22-12.38)$ & \\
\hline Teacher (\%) & $25(23.2)$ & $0.78(0.52-1.18)$ & \\
\hline Higher education technician (\%) & $9(8.3)$ & $0.93(0.54-1.60)$ & \\
\hline High school educational technician or lower (\%) & $20(18.5)$ & 1 & \\
\hline Physical activity & & & 0.78 \\
\hline Active (\%) & $26(24.3)$ & $1.06(0.72-1.55)$ & \\
\hline Sedentary & $27(25.2)$ & 1 & \\
\hline Smoking & & & 0.44 \\
\hline Yes (\%) & $3(2.9)$ & $0.81(0.50-1.33)$ & \\
\hline No $(\%)$ & $42(40.8)$ & $0.81(0.30-2.17)$ & \\
\hline Postgraduate or specialization (\%) & $14(13.0)$ & $1.52(0.94-2.46)$ & \\
\hline Master's degree (\%) & $9(8.3)$ & $1.07(0.58-1.98)$ & \\
\hline Ph.D. (\%) & $18(16.7)$ & 1 & \\
\hline Distance between the city of residence and work in $\mathrm{km}$ & & & 0.98 \\
\hline Median (IQI) & $61.6(106.6)$ & $1(1-1)^{c}$ & \\
\hline
\end{tabular}

Table 4. Analysis of factors associated with neuropathic pain among patients with chronic pain in the sample $(n=54)$

\begin{tabular}{|c|c|c|c|}
\hline Variables $^{a}$ & Neuropathic n (\%) & Nociceptive n (\%) & $\begin{array}{c}\text { Univariate }-\mathrm{p}^{\mathrm{a}} \\
\text { Gross PR (IC95\%) }\end{array}$ \\
\hline Time of pain (in months) & & & $p=0.16$ \\
\hline Median (IQI) & $24(14.5-56)$ & $30(17.5-75)$ & $0.99(0.98-1.00)$ \\
\hline Location of pain ${ }^{b}$ & & & $\mathrm{p}=0.84$ \\
\hline Head and neck & $3(25.0)$ & $4(9.8)$ & $2.36(0.47-11.75)$ \\
\hline Lumbar spine & $1(8.3)$ & $21(51.2)$ & $0.25(0.23-2.65)$ \\
\hline Upper limbs & $6(50.0)$ & $7(17.1)$ & $2.54(0.59-10.82)$ \\
\hline Lower limbs & $2(16.7)$ & $9(22.0)$ & 1 \\
\hline
\end{tabular}


Table 4. Analysis of factors associated with neuropathic pain among patients with chronic pain in the sample $(n=54)-$ continuation

\begin{tabular}{|c|c|c|c|}
\hline Variables ${ }^{\text {a }}$ & Neuropathic n (\%) & Nociceptive n (\%) & $\begin{array}{c}\text { Univariate }-\mathrm{p}^{\mathrm{a}} \\
\text { Gross PR (IC95\%) }\end{array}$ \\
\hline Pain intensity & & & $p=0.02$ \\
\hline Mean \pm SD & $6.5 \pm 1.7$ & $5.2 \pm 1.7$ & $1.42(1.05-1.91)$ \\
\hline Pain frequency & & & $p=0.004$ \\
\hline Continuous & $4(30.8)$ & $2(4,9)$ & $5.17(1.69-15.79)$ \\
\hline Daily & $5(38.5)$ & $12(29.3)$ & $2.28(0.68-7.56)$ \\
\hline Occasional & $4(30.8)$ & $27(65.9)$ & 1 \\
\hline Treatment for pain & & & $p=0.66$ \\
\hline No & $8(61.5)$ & $28(68.3)$ & $0.80(0.30-2.14)$ \\
\hline Yes & 5 (38.5) & $13(31.7)$ & 1 \\
\hline
\end{tabular}

Table 5. Multivariate analysis of factors associated with neuropathic pain $(\mathrm{n}=54)$

\begin{tabular}{lcc}
\hline Variables & $\begin{array}{c}\text { Adjusted PR } \\
(\mathrm{Cl} \text { a } \%)\end{array}$ & p-value \\
\hline Pain frequency & & 0.004 \\
Continuous & $5.17(1.69-15.79)$ & \\
Daily & $2.28(0.68-7.56)$ & \\
Occasional & 1 & \\
\multicolumn{2}{l}{ a Robust Poisson model. The time and intensity of pain variables were succes- } \\
sively excluded.
\end{tabular}

\section{DISCUSSION}

$\mathrm{CP}$ has reached alarming proportions, becoming a priority concern for the health care systems. By reaching a significant portion of the working-age population, it has negative impacts on employers. Despite this, there is a scarceness of studies that track the prevalence of CP, especially in labor environments in Brazil. The present sample showed a high prevalence was found, placing the institution and the federation in a situation of economic vulnerability and workers in social risks related to the loss of health. A $50 \%$ prevalence of CP was found among active public workers of the institution. This result exceeds most of the previous studies. Three population-based studies conducted in Brazil found prevalence of $28.1 \%$ in São Paulo ${ }^{11}, 41.4 \%$ in Salvador ${ }^{12}$ and $42 \%$ in São Luís ${ }^{13}$. Considering a work environment, a study conducted by Kreling, da Cruz e Pimenta ${ }^{24}$ found an even higher prevalence of $61.4 \%$ among employees of a state university in Paraná. However, that study did not screen for CNP. It is noteworthy that the prevalence of CP is so high in educational institutions. In a study conducted among tobacco farmers, whose mechanical risk is high, they found a prevalence of $8.4 \%$ of pain in the lumbar spine ${ }^{18}$, a result much lower than the one found in the present study, which estimated $20.4 \%$ prevalence of pain in this body area. In other countries, prevalences were always lower and ranged from $19.6 \%$ to $43.5 \%$ in Libya ${ }^{25}$, Morocco ${ }^{26}$, France ${ }^{20}$, and the United Kingdom ${ }^{8}$. These differences can be justified by the cut-off point for the stratification of $\mathrm{CP}$, varying between three and six months, and by the different economic, social and cultural conditions involved.
CNP had a prevalence of $12 \%$ in the sample. This value is worrisome, mainly because this type of pain is related to a worse prognosis and has greater interference in the life of the individuals affected compared to those who only have nociceptive pain ${ }^{17}$. A similar result was found in a population-based study in São Luís that found a prevalence of CNP of $10 \%{ }^{13}$. However, that study included the elderly and retirees, indicating that the prevalence of CNP in the current study is even more serious because it affects explicitly active workers. At the global level, the prevalence of neuropathic pain is 3.9\% in Libya $a^{25}, 6.9 \%$ in France ${ }^{20}$, $8.1 \%$ in $\mathrm{Canada}^{27}$, from 8.2 to $8.9 \%$ in the United Kingdom ${ }^{8}$ and $10.6 \%$ in Morocco $^{26}$. The variation in the outcome found in these studies can be explained by the use of different scales to diagnose the type of pain. In Brazil, the high incidence of CNP is alarming, which requires urgent measures.

In the present study, no differences were found between the sociodemographic factors or lifestyle and the presence of CP. In the literature, there are differences among the predictors for CP, but most of the studies state that its prevalence is higher in females and increases with age $e^{8,11-13,26}$. The size of the sample may have been insufficient to find significance in these associations since the study was not designed to evaluate these outcomes specifically.

The individuals with CNP had a higher prevalence of continuous pain compared to occasional pain. Previous studies have shown that pain characteristics vary significantly among people with nociceptive and neuropathic pain ${ }^{20,26}$. Similarly, it was found in these studies a more intense pain and a longer time since the onset of the symptoms and the location in the limbs among those with CNP. These were also the findings of the study conducted by De Moraes Vieira et al. ${ }^{13}$, with the additional finding of a higher daily and continuous pain frequency among patients with CNP. The higher frequency of pain among those with CNP suggests a more significant impairment of daily activities, which further affects the ability to work, leads to early retirement and increases the direct and indirect costs for the whole society.

The present study sought a rigorous methodology to get an accurate estimate of the prevalence of $\mathrm{CP}$ and $\mathrm{CNP}$ among workers of a federal institution, using a stratified random sampling and appropriate robust statistical models. It also applied the 
instrument that presented the best results for the tracking of neuropathic pain ${ }^{20,26-28}$. However, the study faced difficulties in getting answers from teachers. Even reaching the calculation of the sample and applying adequate techniques for randomization, the high refusal in this group of workers may have led, to some degree, to a selection bias. The fact that the present study was conducted with a particular population of workers, and the finding of the prevalence of CP and CNP was higher than most of the previous studies, suggests an association with being a public worker. This association was not tested since a comparison group of non-public workers was not used. However, it can serve as the basis for future studies on this subject. The cross-sectional design did not allow to establish causal or trend inferences. However, as an exploratory study, it provides relevant data for longitudinal studies, socio-educational interventions in occupational health and public health policies.

\section{CONCLUSION}

In conclusion, the $50 \%$ prevalence of CP and $12 \%$ of CNP was found among the employees of a higher education institution located in the countryside of the state of Bahia, Brazil. No associations were found between sociodemographic characteristics or lifestyle and the presence of CP. Continuous pain was more prevalent among people with CNP. The study broadens the knowledge about the epidemiology of pain in the workplace, showing the higher prevalence of CNP found so far, both in national and international studies.

\section{ACKNOWLEDGMENTS}

To the participants for the time and collaboration in the study, as well as to the entire team of the Pro-Rectory of People Management of the Federal University of the Recôncavo da Bahia for the support and provision of the necessary data for this study.

\section{REFERENCES}

1. IASP. Classification of Chronic Pain: descriptions of chronic pain syndromes and definitions of pain terms. In: Merskey H, Bogduk N, editors. $2^{\text {nd }}$ ed. Seattle: IASP Press; 1994. 222p.

2. Tomé-Pires C, Solé E, Racine M, Galán S, Castarlenas E, Jensen MP, et al. The relative importance of anxiety and depression in pain impact in individuals with migraine headaches. Scand J Pain. 2016;13:109-13.

3. Uhlig BL, Sand T, Nilsen TI, Mork PJ, Hagen K. Insomnia and risk of chronic musculoskeletal complaints: longitudinal data from the HUNT study, Norway. BMC
Musculoskelet Disord. 2018;19(1):128.

4. Bair MJ, Robinson RL, Katon W, Kroenke K. Depression and pain comorbidity: a literature review. Arch Intern Med. 2003;163(20):2433-45.

5. Relieving Pain in America: a blueprint for transforming prevention, care, education, and research. Institute of Medicine (US) Committee on Advancing Pain Research, Care, and Education. Washington (DC): National Academies Press (US); 2011.

6. Stewart WF, Ricci JA, Chee E, Morganstein D, Lipton R. Lost productive time and cost due to common pain conditions in the US Workforce. JAMA. 2003;290(19):2443-54.

7. Saastamoinen P, Leino-Arjas P, Laaksonen M, Lahelma E. Socio-economic differences in the prevalence of acute, chronic and disabling chronic pain among ageing employees. Pain. 2005;114(3):364-71.

8. Fayaz A, Croft P, Langford RM, Donaldson LJ, Jones GT. Prevalence of chronic pain in the UK: a systematic review and meta-analysis of population studies. BMJ Open. 2016;6(6):e010364

9. Takura T, Ushida T, Kanchiku T, Ebata N, Fujii K, DiBonaventura Md, et al The societal burden of chronic pain in Japan: an internet survey. J Orthop Sci. 2015;20(4):750-60

10. Von Korff M, Scher AI, Helmick C, Carter-Pokras O, Dodick DW, Goulet J, et al United States National Pain Strategy for Population Research: concepts, definitions, and pilot data. J Pain. 2016;17(10):1068-80.

11. Leáo Ferreira KA, Bastos TR, Andrade DC, Silva AM, Appolinario JC, Teixeira MJ, et al. Prevalence of chronic pain in a metropolitan area of a developing country: a population-based study. Arq Neuropsiquiatr. 2016;74(12):990-8.

12. Sá K, Baptista AF, Matos MA, Lessa I. Prevalence of chronic pain and associated factors in the population of Salvador, Bahia. Rev Saude Publica. 2009;43(4):622-30.

13. De Moraes Vieira EB, Garcia JB, da Silva AA, Mualem Araújo RL, Jansen RC. Prevalence, characteristics, and factors associated with chronic pain with and without neuropathic characteristics in São Luís, Brazil. J Pain Symptom Manage. 2012;44(2):239-51.

14. Lambert M. ICSI releases guideline on chronic pain assessment and management. Am Fam Physician. 2010;82(4):434-9.

15. Liedgens H, Obradovic M, De Courcy J, Holbrook T, Jakubanis R. A burden of illness study for neuropathic pain in Europe. Clin Outcomes Res. 2016;8:113-26.

16. Vissers KC. The clinical challenge of chronic neuropathic pain. Disabil Rehabil 2006;28(6):343-9.

17. Alves MI. Compreender a Dor Neuropática Crónica. 2009.

18. Meucci RD, Fassa AG, Faria NM, Fiori NS. Chronic low back pain among tobacco farmers in southern Brazil. Int J Occup Environ Health. 2015;21(1):66-73.

19. Höfelmann DA, Blank N. [Self-rated health among industrial workers in Southern Brazil]. Rev Saude Publica. 2007;41(5):777-87. Portuguese.

20. Bouhassira D, Lantéri-Minet M, Attal N, Laurent B, Touboul C. Prevalence of chronic pain with neuropathic characteristics in the general population. Pain 2008;136(3):380-7.

21. de Lima DF, Levy RB, Luiz Odo C. Recommendations for physical activity and health: consensus, controversies, and ambiguities]. Rev Panam Salud Publica. 2014;36(3):164-70. Portuguese.

22. Petersen MR, Deddens JA. A comparison of two methods for estimating prevalence ratios. BMC Med Res Methodol. 2008;8:9.

23. Coutinho LM, Scazufca M, Menezes PR. [Methods for estimating prevalence ratios cross-sectional studies]. Rev Saude Publica. 2008;42(6):992-8. English, Portuguese.

24. Kreling MC, da Cruz DA, Pimenta CA. [Prevalence of chronic pain in adult workers] Rev Bras Enferm. 2006;59(4):509-13. Portuguese.

25. Elzahaf RA, Johnson MI, Tashani OA. The epidemiology of chronic pain in Libya: a cross-sectional telephone survey. BMC Public Health. 2016;16(1):776.

26. Harifi G, Amine M, Ait Ouazar M, Boujemaoui A, Ouilki I, Rekkab I, et al. Prevalence of chronic pain with neuropathic characteristics in the Moroccan general population: a national survey. Pain Med. 2013;14(2):287-92.

27. VanDenKerkhof EG, Mann EG, Torrance N, Smith BH, Johnson A, Gilron I. An epidemiological study of neuropathic pain symptoms in Canadian adults. Pain Res Manag. 2016;2016:9815750.

28. Bouhassira D, Attal N, Alchaar H, Boureau F, Brochet B, Bruxelle J, et al. Comparison of pain syndromes associated with nervous or somatic lesions and development of a new neuropathic pain diagnostic questionnaire (DN4). Pain. 2005;114(1-2):29-36. 